\title{
THE GOOD, THE BAD, AND THE UGLY: A PRAGMATIC APPROACH FOR REVISITING ETHICS AND INTERNET POLITICS $^{1}$
}

\author{
Osvaldo Saldías ${ }^{2}$, Theresa C. Züger ${ }^{3}$
}

\begin{abstract}
The article stems from a broader ongoing research project on Internet, Global Constitutionalism and Ethics. We attempt to brisk up traditional ethical thinking against the background of urgent questions concerning the Internet. By revisiting the perspective of cosmopolitanism that was inspired by Kant's thesis of a universal rationality, reflecting upon Hanna Arendt's critical analysis of moral claims and political outcome, and building on Capurro's "net ethics", we introduce a perspective aiming at an intercultural understanding that might guide our actions in global politics in times of the so called digital era.

The article advances the idea by Hannah Arendt that a concrete example as such has moral relevance and therefore makes a case to foster this approach using "best practices" as explicit examples to follow.
\end{abstract}

Key words: ethics, Internet, politics, governance, digital era, Hannah Arendt, global constitutionalism, IGF

El Bueno, el Malo y el Feo: Un enfoque pragmático para la revisión de una ética y una política para Internet

Resumen: Este artículo deriva de un proyecto de investigación mayor sobre Internet, Constitucionalismo Global y Ética. En él intentamos avivar el pensamiento ético tradicional a la luz de preguntas urgentes relativas a Internet. Pasamos revista a la perspectiva del cosmopolitismo, reflexionando sobre el análisis crítico de aseveraciones morales y los resultados politicos, y, finalmente, construyendo sobre la "net ethics" de Capurro, presentamos una perspectiva que apunta a un entendimiento intercultural capaz de guiar nuestras acciones en la política global en tiempos de la denominada "era digital".

El artículo utiliza de idea de Hannah Arendt que afirma que un ejemplo concreto, como tal, tiene relevancia moral y, por ende, propone este enfoque relativo a las "mejores prácticas" como un ejemplos explícitos a seguir.

Palabras clave: ética, Internet, política, gobernanza, era digital, Hannah Arendt, constitutionalismo global, IGF

O Bom, o Mau e o Feio: Um enfoque pragmático para a revisáo de uma ética e uma política para Internet

Resumo: Este artigo deriva de um projeto de investigação maior sobre Internet, Constitucionalismo Global e Ética. Nele tentamos avivar o pensamento ético tradicional à luz de perguntas urgentes relativas à Internet. Passamos em revista a perspectiva do cosmopolitismo, refletindo sobre a análise crítica de asseveraçôes morais e os resultados políticos, e, finalmente, construindo sobre a "net ethics" de Capurro, apresentamos uma perspectiva que aponta para um entendimento intercultural capaz de guiar nossas açóes na política global em tempos da denominada "era digital".

O artigo utiliza da ideia de Hannah Arendt que afirma que um exemplo concreto, como tal, tem relevância moral e, por fim, propõe este enfoque relativo às "melhores práticas" como um exemplos explícitos a seguir.

Palavras-chave: ética, Internet, política, governança, era digital, Hannah Arendt, constitutionalismo global, IGF

\footnotetext{
${ }^{1}$ The authors would like to thank the organizers of the international conference "Ética y Poder en las Relaciones Internacionales", at the Institute for International Relations, University of Chile, as well as the Alexander von Humboldt Institute for Internet \& Society for their support. We are especially grateful to Rüdiger Schwarz and Kaja Scheliga for their comments to earlier versions.

${ }^{2}$ Lawyer, PhD, M.A. in Political Science, currently Post-Doctoral Researcher, Alexander von Humboldt Institute for Internet \& Society, Berlin, Germany

Correspondencia: saldias@internetundgesellschaft.de

${ }^{3}$ Magister Artium in Media and Cultural Studies, Philosophy and German Philology \& Literature, currently Doctoral Researcher, Alexander von Humboldt Institute for Internet \& Society, Berlin, Germany
} 


\section{Introduction}

Our century is facing the consequences of a vast and outrageous development towards global connections in nearly every sphere of human lives starting with our food, travel, our economic system up to our communication. The Internet is an incubator for this development. It is fostering the change of infrastructures, but even more importantly: it is changing our minds, for the vision of a world society becomes tangible. The Internet is seen as "the New Frontline in the Work for Freedom in the World" (1:17), what clearly points out the normative character this technical invention possesses. The history of media shows, that technical innovation always comes with the normative question according to which normative principles the emerging form of interconnection or the change of societies should be guided by. Ethical arguments concerning the Internet can be seen as an attempt to figure out how and under what conditions global society could come closer to the vision of global citizens and a peaceful world society. The rise of the idea of a world society has been observable during the past decades in social science(2) as well as in civil society. Though, the vision of a world-citizenship has a long tradition in the philosophical discourse that arouse around the questions how humanity could manage to live in peace. Politics, as well as normative thinking, is still trying to get a grip on the vast evolution of technologies and their backdrops on society that introduce changes on a global scale(3).

The question that arises from this approach is what kind of ethics could provide a gain to political practice, since ethics as part of the practical philosophy, is facing challenges too, that we will try to describe. Our research approach, following a normative perspective, entails asking whether recent practices observable in times of a digital era governance support the vision of a world-citizenship, and also thinking towards an alternative perspective, that takes ethical theories pragmatically into account in order to foster new ideas for political processes of global politics. Rather than remaining in theoretical thought, we try to extract reflexive instruments that can be applied to political institutions, law proposals or politi- cal processes to tackle the question of normative goodness for world-citizenship. We end our argument with the question whether this pragmatic approach could inspire law in general and global constitutionalism in particular.

\section{The idea of world peace in occidental ethics}

Ethics as a meta-level of moral decision-making, does not simply lay out the morally good, but offers theories about how one could derive it from different presumptions. Ethics has been ranking quite high on the agenda of global politics thanks to recent developments. Nonetheless, one should not forget that the contributions of ethical thinking to common grounds in global politics go far back in history. Not the first, but probably the most prominent thinker in occidental philosophy who created a cosmopolitan worldview was Kant, who during the European Enlightenment coined the term "world citizenship" in an article named "Idea of a Universal History on a CosmoPolitical Plan" published in 1784. Kant believed that humanity would change for the better over centuries. He predicted, that the federal community of states would by the force of reason come to the conclusion of creating a peaceful world community based on international law(4). In his "metaphysics of morals" he explains his idea of world citizen rights that combine all nations in peace, but not necessarily in friendship. The idea of world peace must be set a priori by reason, according to Kant, as the ideal for a juridical connection between nations(5). Even more concrete he stated three necessary conditions for eternal peace. ${ }^{4}$ First: a republican state in which state-power acts up to the common will; second: federalism must be grounded on the alliance between free nation states; and third: the free and unlimited right to travel for all world citizens(6). From the human talent for reason, Kant derived the ability to come to morally good decisions and the best orientation for human interaction in the world. According to his ideas, the categorical imperative is comparable to a compass that processes the rational question whether a given decision is

${ }^{4}$ This is only a very brief version of Kant's approach to eternal peace. Besides these three necessary conditions he argued in much more detail how, in his view, eternal peace would be achievable (See Kant, 1966). 
desirable to be a natural law. Between the lines of western laws Kant's handwriting can be found in many cases. Obviously, Kant's deontological ethics influenced national law setting in western societies.

In giving concrete advice to the individual in an interconnected world with the complexity of ours, it is much harder to derive the morally good from the hypothetical question of the categorical imperative. This overwhelming complexity always creates the need for simplification. Thereby it is possible to derive moral advice in general, but the reality very often does not reflect these model situations. In everyday decisions, in personal as well as in political spheres, reasonable interests can be in tension; an additional problem are the wide reaching consequences of our actions in the global context that we can sometimes hardly predict. Besides the fact that we do not live in a model world, there is another problem with Kant's moral philosophy as well as with other approaches: the human is understood as a being that is generally good. As in many religious traditions, sins and mistakes are seen as weaknesses. Kant maintains, that human will cannot be free and evil at the same time.

After Kant many philosophers followed his way by thinking ethical questions in a global dimension. However, the deontological ethical approach is missing an important fact, maybe even the most important aspect for ethics that truly aims to set values in an intercultural space like the Internet: it is based on the occidental and therefore a mono-cultural understanding of reason(7). If ethics does not overcome this mono-cultural perspective, how can it be able to give advice to politics in a sphere of pluralism?

Kant's deontological ethics based on the idea of a universal rationality, is still an -if not the most - influential tradition in occidental ethics. This fact, as we will show later, leads to a key problem, that intercultural understanding in the global ethical debate is facing.

\section{Arendt's critical approach to ethics}

What has been suggested above regarding the goodness of the human being, can be seen quite differently, even from a western viewpoint, against the backdrop of World War II. Hannah Arendt, as a German Jewish philosopher that immigrated to America during World War II, notably influenced thinking in western political ethics, even though she is not primarily known for her ethical theory but rather for her political philosophy, which for our concern is no less valuable. Arendt did not develop a coherent ethical theory. She rather deconstructed the moral understanding of society by her critical political philosophy. For Arendt the political is a normative model and a mode of handling questions of mutual life.

In her lecture "Some questions of moral" that she held in 1965 in New York, she asks what the human might possibly still rely on regarding moral questions, after something happens that should have never happened(8:99). Arendt criticized Kant's ethical position strongly and argued that the Holocaust is one of many evidences for the badness in the human condition. She assumes that humans are not born with universal morals, like many other moral theories suppose. She classifies our notion of what is right and wrong as conventions and habits close to the etymological meaning of the word "moral". In her view, these conventions carry a high risk of failure. In Arendt's understanding morality is not self evident(9:50). Following Sokrates, she sees a moral institution in the self, based on the idea of the doubled self that holds inner dialogue. For instance, someone who committed murder would be his own witness and would have to live with a murder for the rest of his life. Other than traditional moral philosophy, Arendt does not recognize the ability of the self to conclude ethical principles in general. The boundaries between good and bad, that the self imposes to itself, are drawn differently for each person, each country, each century(9:86). But the boundless, extreme evil is only possible where individuals have no self-grown roots, which in Arendts thinking means, where humans do not practice thinking in solitude and question their own memories. The self that forgets what 
it has done has no need to struggle with the past and change for the future. On the other side, it is the self that can analyse the predominant set of rules and norms and come to the conclusion that they are not sufficient or ethically acceptable, even against strong opposition. Due to this ability of the self we can witness protests, resistance and individuals taking high personal risks to create awareness over norm setting, which they consider unacceptable. Arendt concludes that the self is most relevant in times of political crisis, that it has the ability to make an exception to moral standards(9:91). The problem that Arendt sees, is that this dialogue with the self, the process that she terms as thinking, can be missing and therefore humans are able to commit terrible deeds without ever having issues with living on with their past. Arendt identifies thinking and remembering as two actions to take against the morally bad and even though both need to take place on the individual level, one could ask the question how political decisions could rather strengthen this ability of the self or undermine it. Arendt's understanding of the political differs from a common understanding but is crucial for the use of her ethical implications. She states, handling all affairs by means of words that convince, and not by constraint or violence, to be political means. The political mode is free of egoistic interests. In Arendt's view, the goal of politics is common welfare, therefore political process should not simply balance between conflicting interests as "addition of private interests" (10:243), but ask for the good in a common sense. One of the core elements of Arendt's philosophy is the distinction between power and violence, which breaks the tradition of using these words synonym or in close connection(11:145-208). Arendt points out, that they are opposites. All against one is the most extreme case of power. One against all is the most extreme case of violence (11:172). Power is always a matter of multitude, based on the alliance which shares an opinion (which is not the same as interest). All political institutions are manifestations and materializations of the power of people. They fall and freeze in the moment when people withdraw their vivid power (ibid.). The solely human ability to act is the precondition for political power and the political mode. The political action gives the human the ability to create something new in the world. "The fact that man is capable of action means that the unexpected can be expected from him" (12:178). Only the joint actions of humans that create power, in Arendt's view, meet the requirements of the human condition, that not one human but a plurality of humans live on this earth(13:115).

As we mentioned, Arendt gave little credit to Kant's categorical imperative, as she considered it to be too rigid for realistic human decisionmaking(14:181ff). To overcome the problem of hypothetical ethical thinking and simplification in model questions, she advances the idea that examples bear considerable ethical strength. An example, like, say, Achilles for bravery, is something concrete, something explicit that represents a principle. On the one hand, an example corresponds to the principle we have in mind, but on the other hand, it is specific and extraordinary. Other than any given general rule, an example describes unique circumstances that take account of the individual action. Arendt explains her thought by —of course an example - of a table. We have an idea of a table, that is schematic in our minds, we can also collect all necessary characteristics that all tables have in common, which would create an abstract understanding of a table. What we could also do —and Arendt suggests this analogously for ethical principles- is to look for the best of all tables and take it as an example of how we think tables should be constructed. The importance of the example in moral questions is even more straightforward considering the immaterial nature of moral concepts. It is more likely to agree on what a table is, than on human goodness. The example gains even more practical value against the backdrop of an intercultural approach to ethics. The concrete example, as opposed to mere theory, might be a good starting point for ethical discourse to approach on an intercultural basis.

Just as the idiosyncratic nature of national laws makes them so different - if not incompatibleto the laws of other states, ethical tradition is highly influenced by culture and as well by time. If someone would observe the change of ethical 
models over centuries in only one country, he or she would get a colorful picture of values, norms, ethical reasoning and moral standards. Religious beliefs, as well as more rational approaches to the moral good, come to different and sometimes contrary answers to the same ethical question. Even more complicated: The question, what the highest good itself is, that a good person should serve, is answered with different values, which are interlaced in our life so tightly, that it is hard to even realize that there are different ways of seeing the goal of a good life. Assumptions, which are basic for one ethical tradition, for example the belief in the rational power of the individual to determine right from wrong, can be absurd to other ethical lines of argument. This diversity not only concerns ethical theories about human interaction in the world but also grounds in different views on human mankind. Rafael Capurro addresses the challenges of the information society, and thereby draws general ethical assumptions. He refers to a phrase by Nietzsche, in which he states, that we find ourselves in an "age of comparison". What he means is that no ethics should be seen as universal and should open up its isolated culture of norms and customs for comparison with the other(15). Before we reach an ethical understanding at all, we need to acknowledge existing differences by means of comparison. His theory itself is influenced by pluralism. There are clear parallels to Aristotle's idea of virtues and to Foucault's concept of the "care for the self" (16-17), that reaches for a high level of selfresponsibility of the individual. Capurro's ethical approach aims for a "world information ethos", which means a minimal moral consent based on the Universal Declaration of Human Rights. The way to this ethical goal is paved by intercultural dialogue that holds account for the differences in moral understandings. Capurro solves the problem of the competition of diverging ethical approaches with an interesting turn. He sees the different approaches in philosophical tradition, as the deontological and utilitarian, as potential enrichment of thought and also as a cure against one-dimensional thinking and biased action(18). Instead of formulating normative imperatives in forms of the "you shall", his approach describes a moral discourse that rather aims at offering each other the appropriate possibilities of actions, that can lead to concrete and consent solutions, which he calls "ethics of offer" (18)5. He formulates a quite open imperative for the information society, that exemplifies his thinking: Act as if the maxims of your behaviour tolerate a networked global public $(18)^{6}$.

The point Capurro states for information ethics is valid for ethics in general: they have been dominated by western culture and lack an intercultural perspective. A look at the ethical discourse between Latin America and the west, exemplifies the conflict that ethics are facing on a global level. The key question is, how ethics are legitimized. Many Latin American philosophers reject the claim of a universal rationality (like Kant proposed). This position and any others that follow this universalistic approach (like Habermas' and Apel's) are regarded as eurocentristic, dogmatic, fundamentalistic and imperialistic, which is from a historical perspective a comprehensible position. Raoul Fornet-Betancourt introduced the idea of cultural viewpoints. He argues that philosophy is always developed form a certain viewpoint of the thinking individual, that is bound to its consciousness within its language, culture, history and context. He rejects any "so-called universal philosophical perspective" (19:31), which he finds to be so present in western occidental philosophy. The reflection on the interdependence of philosophy and culture is an important step towards intercultural ethics and holds truth for any individual. Intercultural philosophy and especially intercultural ethics are a major challenge for recent philosophy and there is a current need to foster intercultural ambitions in philosophical institutions to achieve this difficult task. To truly inspire global politics for new models of governance, ethics as philosophical practice and scientific institutions must overcome the dominant habit of mono-cultural

\footnotetext{
${ }^{5}$ Capurro agrees with Habermas that discourse is the ethical method to reaching solutions. But Capurro does not mean a the theoretical construct of discourse like Habermas, he means actual dialogue. Capurro and Habermas differ in the assumption, that all differences actors in this discourse might have, are rationally solvable, with regard to the "unforced force of the better argument" (21:161), as Habermas calls it. Habermas' discourse ethics stands in the tradition of Kant's belief that there is a binding force that ethical reasoning can rely on for all of humanity.

${ }^{6}$ Translated by the authors.
} 
self-referencing and open itself to an intercultural philosophy, which would mean nothing less than a new understanding of philosophy. Phenomena as the Internet or other global interconnections represent a chance for this humanistic shift, since they connect cultures in practical interests.

Hannah Arendt's view of the political embraces the thought of plurality - she even states that politics deals with the being together and being with each other of the different(20:12). In political modus she situates the possibility to act freely and unfold in difference to others to mutually shape the world. The "World" in Arendt's understanding is not a self-evident connection of human beings. It is a relation that is constituted by joint actions.

\section{Pragmatic approach to ethical reflection}

The danger each ethical theory is facing is isolation in its own theoretical framework. Especially the political philosophy of Arendt is rich on reflection about ethics, but it is rather problematic to derive a set of precepts from it that can be applied to politics to sketch out an ideal kind of politics. However, we think that Arendt's critical thinking and other mentioned approaches can provide us with the right instruments to reflect on the current phenomena and developments we experience in the digital age. Therefore we engage in the attempt to derive pragmatic reflective procedures from the theories we sketched out as an inspiration for further discussion. We don't claim to develop a full-blown method to evaluate political processes conclusively, but rather aim to point out the potential for moral orientation and reflection this attempt is offering. We see this step as experimental thinking, which will have to prove its value in further practice.

Looking at Arendt's deconstruction of occidental morals we learn that there is normative strength in the individual's process of thinking and remembering.

To put it differently, the potential to evaluate its moral distinctions for the individual is bound to the possibility to reflect on it and see it in contrast to earlier decisions and actions. In analogy to a political phenomena one could ask:

How does a specific phenomena supply a basis for reflection for each individual as a political being?

A further question arising against this backdrop refers to the conditions, which are determining the basis for reflection in a concrete case. From our point of view this question supplies ground for further research.

Taking into account Arendt's statement about the example as an instrument in moral discourse to formulate the ideal outcome of an idea in order to open it to discourse, one could ask:

What is the outcome, when we address normative dimensions by analyzing individual aspirational examples?

The third idea, that we want to take into account is the idea of pluralism. The political events that we would like to address face a reality of diversity, as we explained above. One could ask:

How does this specific phenomena represent pluralism in its evolution and outcome?

These are just a few of the possible questions that could be asked to foster reflection on political phenomena, in our case especially phenomena in the field of Internet politics. We don't aim to develop a coherent ethical theory by this attempt nor guiding ethical principles in a direct way. The gain of this idea is from our view the identification of underlying normative discourses and the possibility of their reflection and comparison, following Capurro's statement that we live in an "age of comparison".

\section{The challenge of new forms of politics}

Scholars of "Global Constitutionalism" are currently asking about the foundations and conditions that could lead to the emergence of global

\footnotetext{
${ }^{7}$ Pernice (forthcoming); for a recent review cf. Wiener(25); as well as the new scholarly series of publications devoted to the topic of global constitutionalism by Cambridge University Press.
} 
forms of governance that gain their legitimacy from all world citizens. Yet, it is still a project in the making that could benefit from an eventual multiplication of perspectives on good global rules and governance. On the other hand it also shows, that the idea of conveying concepts like common good, human dignity, rule of law into the global dimension is not a mere utopian vision anymore. Instead it has developed much further; maybe the furthest ever in human history.

Recent developments show the necessity for ethical contemplation in global politics in general and for the Internet in particular. It has been suggested by some scholars that the politics of Internet Governance hinges around functional as well as technical solutions(22), rather than a reflecting mode that reinforces shared values; other scholars, on the other hand, understand the Internet as a moral space as it mediates between us, grounding a "proper distance" between the users $(23,24)$. But then, we get constantly confronted with moral claims when it comes to the control over the Internet. Indeed, most decisions taken in regard to the design of the net's framework, which guides all everyday decisions of users and companies, have been taken based on norms and values. In many cases this ethical diversity works without attracting attention, in some cases though, we face irreconcilable conflicts. The question is how these ethical approaches could combine for the better.

A critical circumstance that affects the existing diversity of norms is a current shift of power at the global level. National states are losing their power over several spheres of activities, which are interconnected and correlated in global networks. The Internet is only one of these spheres, in which national power alone can no longer guarantee certain rights or the rule of law, e.g. in cases of intellectual property or cybersecurity. Many interactions by individuals or organizations simply overcome the borders of their home nations reach. The Internet is setting new boundaries, which on the flip side creates new fields to play on and it is unlikely that there will ever be a vacuum of rules and power in any given social space. ${ }^{8}$ Quite more realistic is the overtaking of those, who are the fastest to establish new orders -in case of the Internet it certainly is the economic and technological sector who took on this role(22:72ff.), besides the national states who try to keep the control over the network, which they still manage to take, as recent actions of the ITU show?. Due to the extraordinary history of the Internet there are also other players on the field, such as civil society organizations and even more obvious - the users themselves. The technical possibilities of the Internet give quite some freedom to any individual in front of a screen, who has skills in using it.

National states are certainly acknowledging these challenges. The available instruments, however, are not unlimited. Unless states exercise sheer power or effective diplomacy at international level to promote their normative views about the Internet, they will ordinarily resort to legal means. The global reach of the Internet becomes a challenge that is often met with the traditional international-toolkit made available by the experience in other fields like trade law, environmental law, or warfare law. Because the Internet is a global phenomenon that permeates many different national jurisdictions, states resort to promoting international agreements (see latest effort to re-articulate ITU), harmonizing laws (see the latest proposal for the EU's Regulation on Data Protection), or using traditional national rules of conflict that arbitrate between two competing legal systems. In theses cases, the legitimacy of such legal processes resides basically on the quality of representative democracies, where elected legislators enact binding rules. The reach of legal statutes, however, does hardly cover the scope of challenges at the global level. States become aware of this, and progressively empower new governance networks to tackle these challenges. Anne Marie Slaughter ex-

\footnotetext{
${ }^{8}$ There might be an absence of statehood in some regions and areas; but not a total absence of power. see e.g. the research project "Governance in Areas of Limited Statehood", funded by the German Research Council.http://www.sfb-governance.de/en/index.html

9 The ITU (International Communication Union) is considering to expand its regulatory authority to the Internet. This intention caused wide reaching protests in the economic sector and in civil society. For more information about the ITU visit: www.itu.com; for more information about the protest visit: https:/www.cdt.org/ files/pdfs/CDT-ITU_WCIT12_background.pdf, or http://bestbits. igf-online.net/statement/
} 
plored the latter in regard to the regulation of global phenomena. State power can be jointly exercised by state officials who gather in more or less formalized trans-national networks. Judges, for instance, talk to each other in international meetings and cross-fertilize themselves intellectually; regulators, like the central bankers, discuss global solutions in fora like the Basel Committee within the Bank of International Settlements(26). In the case of Internet policies, data protection authorities are daring coordination like they recently did in the International Data Protection and Privacy Commissioners' conference in Punta del Este $2012^{10}$.

These governance networks have advantages: they are flexible because they do not operate under the hierarchy of the national state. They are efficient, because they address problems among peers or like-minded interlocutors. They are very technical, because they are not in the ordinary political spotlight; therefore, they face little public scrutiny. However, this implies that they might have little legitimacy because they have not been elected to represent their people, they are hardly accountable to anyone and manifestly nontransparent. At best, they will try to make good decisions that can prevent a spread of overt public disapproval.

Recently, initiatives that explore new forms of public-private governance have been under public scrutiny. Following the approach of the "doit-yourself-diplomacy", some global players from the digital sector have engaged in global politics with a view to contributing to the spread of democracy and a free Internet ${ }^{11}$. These endeavours can have legitimate goals; and yet, as private corporations have their own economic interests, observers are increasingly questioning whether the principles and goals that inspire these ideas are actually met in practice. It is admittedly challenging to assess their legitimacy, or measure their concre-

\footnotetext{
${ }^{10}$ See http://privacyconference2012.org/english/

${ }^{11}$ See also: McCurry J./Kaiman J.: Google's Eric Schmidt says North Korea must open up to internet as visit ends. Available at: http:// www.guardian.co.uk/world/2013/jan/10/north-korea-internetschmidt-visit (30.01.2013) or Sang-Hun, C.: American group begins private trip to North Korea. Available at: http://www.nytimes. com/2013/01/08/world/asia/bill-richardson-and-eric-schmidt-ofgoogle-visit-north-korea.html (30.01.2013).
}

te contribution to the common good. We argue, that it is possible, and also helpful, that we begin addressing these kind of political engagement through an ethical perspective; a reflective notion of ethics that takes into considerations that we all face a common challenge, but at the same time, acknowledges that we do not necessarily share the same normative expectations about the Internet.

The lessons taught by the extremely violent 20th century, is that liberal democracies seem to be the only safeguard against mutual destruction. Contrary to authoritarian regimes, where power resides in few, legitimate power of all democratic states is held by the citizens. Even if there are many fields of world politics that are shaped by actors that stand beyond the national state, it is important to remember that it is still the citizens of the world who hold the legitimate power. Therefore, instead of candidly accepting or vehemently rejecting any initiative in the name of the people of the world, we suggest that it is possible for the world citizens to engage in a mutual conversation based on acknowledging and respecting the differences.

We set forth the foundations of our approach in the next section.

The structural level of the Internet -the framework of interaction- entails a remarkable ethical preposition, and its legal regulation is a major issue for Internet Governance(18). This preset of infrastructure is mainly ruled by decisions of governments and companies and their quality decides over crucial ethical values for society and individuals. If, as we stated, core rights and the rule of law cannot be protected by national states alone within the suggested global network, then the perspective of ethics in the long run could reach out for new models of agreement to sustain existing world citizen rights in the Internet.

Internet Governance provides a good example of an attempt to initiate new models of governance on global phenomena, that is surely worth analyzing from a critical normative perspective.

The Internet Governance Forum (IGF) represents 
a new attempt in global politics and norm-setting(27). The IGF is hosted and initiated by the United Nations, takes place yearly since 2006, last time in November 2012 in Baku ${ }^{12}$. The willingness to step ahead for new forms of government is on the one side due to the engagement of several UN initiators, on the other side the structure of the forum follows the reality of the Internet therefore it is not by accident that the Internet evokes new forms of consolidation. The IGF follows a multi-stakeholder approach by allowing participants from governments, private sector and civil society to gather on the same level $(28)^{13}$. The main focus of the forum is a multi-stakeholder dialogue in workshops and larger panels.

For the approach we want to develop in the near future, the IGF might be a suitable phenomena to discuss. To identify the underlying normative discourse of the IGF, which is supposedly influenced by a multitude of norms and values, we plan to apply the questions we developed and thereby adopt a critical normative perspective. Overall this could bolster our normative discourse about political events or institutions, such as the IGF, by addressing the differences, which now become visible.

\section{Global Ethics and Global Constitutionalism}

How does global ethics interact with global constitutionalism? In order to answer this question, we need to make explicit the notions of ethics and constitutionalism we are referring to. The approach we are suggesting, points out the challenge that global governance means to traditional concepts of moral philosophy and from thereon attempts to explore ethical reflections that offer appropriate approaches to a globally interconnected world. Our focus tries to consider especially the pragmatic dimension of ethics and aims to understand the actual challenges ethical models are facing in political and intercultural practice. In our view the approach to foster the dialogue of intercultural ethics, that accepts differences,

\footnotetext{
${ }^{12}$ For more information about the IGF visit: http://www.intgovforum.org/cms/

${ }^{13}$ The Co:llaboratory Discussion Paper Series devoted a special edition on Internet Policy Making and Multistakeholderism. See Kleinwächter (2011).
}

can be seen as a step forward and would mean to develop a particular attitude based on tolerance rather than a fixed set of moral values.

Besides the intercultural challenge that ethics is facing itself, there is another issue that our approach has to take into account: the gap between ethics as part of a philosophical tradition, and politics that is facing real-time problems. The Internet as a nearly global phenomenon, is not only a challenge for ethics, it is also a chance for philosophy to carry out its own conflicts in a global field of Internet practices. It provokes moral discourse between national states and civil society and poses urgent questions that philosophical discourse could engage in, instead of circling around its own paradoxes and diversities in isolation

Similarly, the notion of Global Constitutionalism is vast. For the sake of our argument, we conceptualize constitutionalism as a process in which power is harnessed by law, and channelled by institutions that derive their legitimacy from the individual(29). Translating this notion to the global dimension is a challenge, because there are few laws -and even fewer institutions- that can fulfill these expectations of exercising the legitimizing authority conveyed from the peoples of the world to global democratic institutions ${ }^{14}$.

We do not have a written global constitution; maybe we never will. There are, however, values that are shared by most of the constitutional traditions in the democratic world, like separation of power, the rule of law, the protection of fundamental rights. This common layer, however, entails only the fundamental ideas of peaceful coexistence. Above them, states have constructed between them - this means inter-nationally- a plurality of principles, laws and regulations that can be extremely different one from another. When it comes to global challenges, this pluralism becomes a hurdle, as the idea of peoples' self-determination and national sovereignty has become hard to relativize in the context of international law.

As in the case of the Internet, an ethical viewpoint could consider pluralistic approaches and

\footnotetext{
${ }^{14}$ Pernice, Ingolf (Forthcoming) Global Constitutionalism.
} 
offer a stage of reflection about what values global politics consider in order to critically examine and evaluate them. In the best case, that could open new fields for action besides the process of functional problem fixing that is met by the pragmatic adaption of norms from other fields. We argue that an ethical approach to global constitutionalism can help fostering the necessary constitutional dialogues that are needed to shape the laws that should govern the Internet.

\section{Conclusion}

In our age, the ambition to change the world for the better and the hope that it is possible by human actions has gone out of fashion. On the one side, this is due to bad experiences of the past that destroyed trust in our own deeds and in the good intentions of others. On the other side, global mass communication confronts us with an overwhelming complexity and the reality of a world society, that also evokes the reaction to concentrate on the known, the local and tangible. Global constitutionalism and intercultural global ethics are both young and ambitious attempts to think towards a cosmopolitan world vision.
Our research project follows a truly trans-disciplinary approach between legal scholarship, political science and philosophy. The outcome so far poses more questions, than it is able to provide answers. The challenge for legal scholars is to abstract from the current legal procedures that currently shape global laws and open themselves to the possibility that law-making could be done differently and better. Philosophy is challenged by the application of theory in political and legal practice. Our aim is to reflect upon emerging practices of politics, identify their implicit normative discourse to critically question it in further research. Further we hoped to show, that ethics, as a humanistic discipline is struggling with intercultural diversity and in itself reveals a long tradition of paradoxes. Nevertheless we hold on to the idea, that ethics can be an inspiration to ongoing and evolving political practice, by addressing its own problems and applying them to current questions, like for instance, the framework and values the global information society is build on. We plan to develop this line of argument further with a view to coming to pragmatic advice and integrating ethical reflection to political practice. 


\section{References}

1. Bildt C. Internet is the Frontline in the Work for Freedom in the World. In: MIND, Multistakeholder Internet Dialog. Ed: Wolfgang Kleinwächter, Vol. 1; 2012.

2. Wobbe T. Weltgesellschaft. Bielefeld: transcipt Verlag; 2000.

3. Chadwick A. Internet Politics: States, Citizens, and New Communication Technologies. Oxford: Oxford University Press; 2006.

4. Kant I. Über den Gemeinspruch: Das mag in der Theorie richtig sein, taugt aber nicht für die Praxis, 5th edition. Frankfurt a. M: 1992.

5. Kant I. Metaphysik der Sitten, 4. Edition. Hamburg: 1966.

6. Kant I. Zum ewigen Frieden. Berlin: Reclam Verlag; 2004.

7. Rojas Hernandez M. Universalismus und Begründung der Ethik. Ein Dilemma der lateinamerikanischen Philosophie. Pololog. Zeitschrift für interkulturelles Philosophieren 2008; 20: S.31-52.

8. Heuer W, Heiter B, Rosenmüller S. Arendt-Handbuch. Stuttgart: Metzler Verlag; 2011.

9. Arendt H. Über das Böse. $5^{\text {th }}$ Ed. München: Piper Verlag; 2012.

10. Arendt H. Elemente und Ursprünge totaler Herrschaft. München: Piper Verlag; 1986.

11. Arendt H. In der Gegenwart. Übungen im politischen Denken II. München: Piper Verlag; 2012.

12. Arendt H. The human condition. Chicago, IL: University of Chicago Press; 1958.

13. Breier K-H. Hannah Arendt interkulturell gelesen. Nordhausen: Traugott Bautz Verlag; 2007.

14. Augstein F. Taten und Täter. Afterword in: Arend, H. (2012): Über das Böse, $5^{\text {th }}$ Ed., München, Piper Verlag; 2012

15. Capurro R. (2007): Intercultural information ethics, 2007. Available at http://www.capurro.de/iie.html (26.01.2013).

16. Capurro R. Ethik im Netz. Wiesbaden: Franz Steiner Verlag; 2003.

17. Foucault M. Ästetik der Existenz. Frankfurt a/M.: Suhrkamp Verlag; 2007.

18. Capurro R. Strukturwandel der medialen Öffentlichkeit, 2000. Available at http://www.capurro.de/zkmforum.htm (Accessed 29.03.2013).

19. Fornet-Betancourt R. Lateinamerikanische Philosophie zwischen Inkulturation und Interkulturalität. Frankfurt a/M: IKO; 1997.

20. Arendt H. Was ist Politik? München: Piper Verlag; 1993.

21. Habermas J. Theorie des kommunikativen Handelns Bd. I. Handlungsrationalität und gesellschatliche Rationa- 
A pragmatic approach for revisiting ethics and Internet politics - Osvaldo Saldias, Theresa Züger

lisierung. Frankfurt a/M: Suhrkamp Verlag; 1981.

22. Lessig L. Code 2.0. New York: Basic Books; 2006.

23. Orgad S. The internet as a moral space: the legacy of Roger Silverstone. New Media and Society 2007; 9(1): $33-41$.

24. Silverstone R. Media and Morality: On The Rise of The Mediapolis. Cambridge: Polity Press; 2006.

25. Wiener A. Global Constitutionalism. In: Oxford Bibliographies Online. New York: Oxford University Press; 2012.

26. Slaughter A-M. A New World Order. Princeton University Press; 2004.

27. Hurwitz J. Whois WSIS; Whois IGF: The New Consensus-Based Internet Governance (Febuary 20, 2007). Available at SSRN: http://ssrn.com/abstract=954209 or http://dx.doi.org/10.2139/ssrn.954209

28. Kleinwächter W. (ed.) Internet Policy Making. MIND, Collaboratory Discussion Paper Series No 1. Berlin, Nairobi, September 2011.

29. Pernice I. The Global Dimension of Multilevel Constitutionalism. In: Dupuy P-M, et al. (eds.) Völkerrecht als Wertordnung. Festschrift für CHristian Tomuschat. Kehl: Engel Verlag; 2006.

Received: February 5, 2013

Accepted: March 25, 2013 